\title{
Un acercamiento a la noción de conceptos estructurantes en el Profesorado de Educación Primaria
}

\author{
Galfrascoli, Adrián ${ }^{1}$
}

\section{Resumen}

La noción de conceptos estructurantes ha sido introducida en el campo de la didáctica de las ciencias durante la década del ochenta. A partir de entonces, se ha hecho un esfuerzo por identificar los conceptos estructurantes de diferentes campos del saber y una vez alcanzado este objetivo, los metaconceptos, como también se los llama, han sido empleados como organizadores de los contenidos en el currículo científico. En Argentina, los Núcleos de Aprendizaje Prioritarios de Ciencias Naturales para la Educación Primaria los contemplan. Esto crea la necesidad de introducir la noción en la Formación Inicial de los maestros. Sin embargo se presentan dificultades en el aprendizaje del sentido de los metaconceptos. En este artículo pretendemos comunicar nuestras reflexionamos en torno a una serie de actividades desarrolladas en el Instituto Superior de Profesorado $N^{\circ} 4$ que han arrojado resultados positivos en términos de mejoras en la comprensión.

Palabras clave: conceptos estructurantes, educación primaria, didáctica de las ciencias 
Galfrascoli, Adrián | Un acercamiento a la noción de conceptos estructurantes...

\section{Summary}

The notion of structural concepts has been introduced in the field of science education during the eighties. Since then, there has been an effort to identify the structuring concepts from different fields of knowledge and once this was achieved, the methaconcepts, as they are also called, have been used as organizers of the content in the science curriculum. In Argentina, the core of Priority Learning of Natural Science for Primary Education take them into account. This creates the necesity to introduce the concept in the initial training of teachers. However, difficulties of teaching the meaning of methaconcepts occurs. In this article we pretend to communicate our reflect ions upon a serie of activities develops in the $N^{0} 4$ Teacher Tralning College that have demonstrated positive results in terms of improvement the understanding.

Keywords: structural concepts, primary education, science education 